Revista Iberoamericana. Vol. LXV, Núms. 188-189, Julio-Diciembre 1999; 479-480

\title{
HACIA UNA NUEVA GEOGRAFÍA DEL COLOR: LOS AFROIBEROAMERICANOS
}

A Susana Jákfalvi-Leiva, maestra y amiga, este saludo amoroso.

Enfrentar desde el ensayo académico los tópicos de lo afroiberoamericano está vinculado íntimamente a la ruptura de nociones y de relatos que han servido de mecanismos explicativos a la hora de dar cuenta de las literaturas nacionales y regionales. Una otredad que vive en el margen de todas las posibles marginalidades, un espacio invisible, frente al cual muchas veces se reproduce la óptica colonizadora. Escribir desde lo olvidado, lo negado y lo invalidado, antes que labor de restauración cuasi arqueológica, es una redefinición de las posturas ideológicas sobre las que se levanta la escritura misma del ensayo historiográfico y, a la vez, entender las contradicciones del procerato, de los intentos de articular en el proyecto modernizador y democratizador gestos que permitieran la diferenciación y la invalidación de voces y estrategias.

Por otro lado, la existencia de escritores y escritoras afroiberoamericanos relata la persistencia del deseo de establecer formatos comunicantes capaces de invalidar todos los mecanismos en que se les censura. Relatar se convierte en una toma de posesión de espacios negados; escribir versos, el mecanismo para construir loci donde los sujetos diaspóricos y sin entidad política se encuentren.

Toda vez que la posmodernidad dedicó parte de sus esfuerzos a hacer patente la multiplicidad que conforma los supuestos homogéneos del discurso que le antecede, el tópico racial se levantó como un ademán sustantivado en el cual ya se abole la realidad biológica - es decir, los supuestos naturales sobre los cuales se organiza el racismo y el código de diferenciaciones que éste supone-ya, por el contrario, se le invoca como marca de identidad para congregar nuevas formas de historicidades. En los últimos veinte años la raza en tanto discursividad ha sufrido interrogantes de todo tipo. Textos como el recogido por el Critical Inquiry y antologado bajo Henry Louis Gates marcan de manera definitoria cómo hablar de raza se constituye en un formato que desestabiliza las formas de conocimiento. Por otro lado, reivindicar el gesto racial ha servido para quien, marcado con el signo racial, ha sido deshistoriado y reclamar su identidad negra es, en la mayoría de los casos, restituir su presencia de un borramiento consistente.

El número que presentamos hoy posee una multiplicidad de asedios y voces ligadas por un lineamiento esencial: dar cuenta de la presencia del mundo afroiberoamericano, su 
pujanza, su valor histórico, la representación agrietada que de éste se hace y la importancia de repensarlo. Asimismo, interroga los espacios historiográficos y teóricos que se han elaborado a la hora de dar cuenta del tópico negro en Iberoamérica. Se propone una nueva geografía del color, en la que Iberoamérica reconoce la pertinencia en su inmediatez de los afroiberoamericanos.

Existen importantes y dolorosas omisiones. Baste decir que hicimos muchos acercamientos y que la summa de las respuestas capaces de cumplir con nuestra proposición inicial la presentamos aquí en un número vigoroso, lleno de interrogantes, incompletudes y sobre todo de propuestas. Que continúe el diálogo.

Dolores Aponte-Ramos

Universidad de Puerto Rico 